\title{
Red Cell Membrane Alteration Associated with "Marrow Stress"*
}

\author{
R. S. Hillman and E. R. Giblett $\dagger$ \\ (From the Department of Medicine, University of Washington School of Medicine and the \\ King County Central Blood Bank, Seattle, Wash.)
}

In the Ii blood group system, the red cells of nearly all normal adults are strongly agglutinated by anti-I and very weakly reactive with anti-i, whereas the reverse is true of the red cells of newborn infants (1). It has recently been shown that in patients with a variety of hematological disorders, i activity of the red cell membrane may increase without a corresponding demonstrable decrease in I activity or increase in fetal hemoglobin (2). Although all of the patients with this cellular phenomenon were moderately to severely anemic, the anemia alone was not an adequate explanation for the observed reactions with anti-i, since the red cells of some anemic individuals were found to react in the same way as those of normal adults. Therefore, a study of the characteristics of erythroid marrow function was undertaken in selected patients to find whether an alteration in red cell production could be correlated with the change in i activity. The results, presented in this paper, indicate that in situations of marrow stress, when red cell production is inadequate to meet either normal or increased demand, there is premature delivery of developing red cells into the circulation. This shortening of normal marrow maturation is associated with increased i activity.

\section{Methods}

Serological methods. Serum containing anti-i from a group A donor (serum Web ${ }^{1}$ ) was neutralized with $\mathrm{B}$ blood group substance and diluted $1: 4$ with saline so that

* Submitted for publication April 16, 1965; accepted July 6, 1965.

Presented in part at the Fifty-sixth Annual Meeting of the American Society for Clinical Investigation, Atlantic City, N. J., May 1964.

Supported by U. S. Public Health Service grants $\mathrm{HE}-05780$ and HE-06242.

$\dagger$ Address requests for reprints to Dr. E. R. Giblett, King County Central Blood Bank, Terry at Madison, Seattle, Wash. 98104.

${ }^{1}$ Kindly supplied by Dr. J. H. Crookston of Toronto. it failed to react at temperatures above $12^{\circ} \mathrm{C}$ with the red cells of 50 normal adult donors of all ABO blood groups. To determine $i$ activity, doubling dilutions of this anti-i preparation were titrated against $2 \%$ suspensions of washed red cells in saline. After 1 hour of incubation at $23^{\circ} \mathrm{C}$, the tubes were centrifuged at the constant speed of a Serofuge 2 for 30 seconds and immediately examined under a dissection microscope. The degree of agglutination was recorded, and titration scores were calculated according to the method of Race and Sanger (3). In this method, each degree of agglutination is assigned a numerical score, so that a semiquantitation of antigen reactivity is obtained. The cells of normal adults had a score of 0 , whereas cells of newborn infants scored between 30 and 50. In many cases, additional titrations were performed with anti-A and anti-I of human origin and anti-H prepared from the seeds of Ulex europeus.

Ferrokinetic studies. Studies of internal iron exchange were carried out by the methods described by Bothwell and Finch (4). Patients were given an intravenous injection of either their own plasma or normal donor plasma (depending on adequacy of latent iron-binding capacity) labeled with 30 to $40 \mu \mathrm{c}$ of citrated $\mathrm{Fe}^{50}$. Frequent specimens of venous blood were obtained during the first 4 hours to determine plasma radioactive iron clearance rates. At the same time, localization of $\mathrm{Fe}^{58}$ was monitored by in vivo counting over the sternum, liver, spleen, and sacrum. Blood specimens were then obtained daily for the next 2 weeks to determine the reappearance of the $\mathrm{Fe}^{50}$ in the hemoglobin of circulating red cells newly released from the marrow. Measuring the interval between the $50 \%$ uptake and $50 \%$ release of the isotope provided a means of estimating the marrow iron turnover time. This value, which reflects the intramarrow red cell maturation time, has been found to be $3.4( \pm .5)$ days in normal adults $(4,5)$. Typical reappearance curves derived from blood $\mathrm{Fe}^{5 \theta}$ activity are shown in Figure 1, which illustrates the progressive decrease in marrow maturation time associated with the stress of increasing phlebotomy.

In some instances, the marrow iron turnover was also determined by plotting against time the number of counts over the sacral marrow, the resultant curve representing the reciprocal of the peripheral blood $\mathrm{Fe}^{5 \theta}$ reappearance curve. This technique was particularly useful for studying certain disease states in which rapid splenic destruction of newly released cells introduced a large error in

\footnotetext{
${ }^{2}$ Clay-Adams, New York, N. Y,
} 


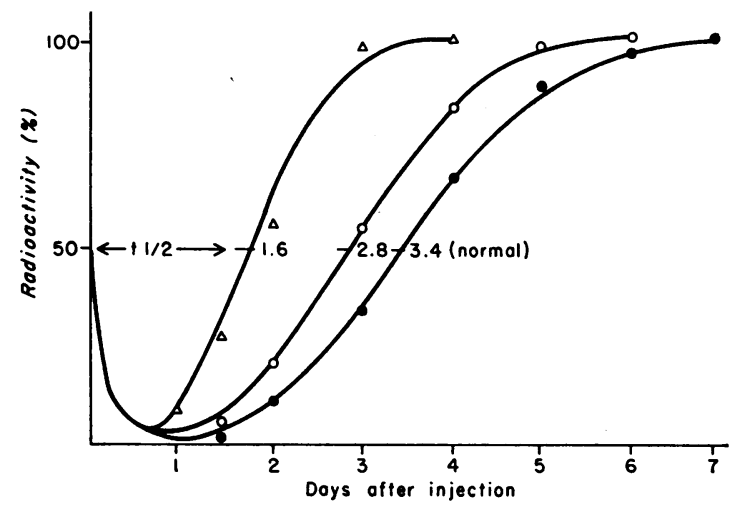

Fig. 1. Radiolron Reappearance curves measured in A hematologically NoRmal Patient (L.T.) SUBJEcted TO REPEATED PHLEBOTOMY. The initial curve, before phlebotomy, had a normal $t_{1}$ reappearance of 3.4 days. This value shifted to 2.8 days and then to 1.6 days under the stress of increasingly severe blood loss, indicating a marked decrease in intramarrow transit time of developing red cells. This was accompanied by the appearance of reticulocytes with prolonged peripheral blood maturation time, consistent with their premature release from the marrow.

the reappearance curve. In two thalassemic patients with severe intramarrow red cell destruction and rapid recirculation of iron, both measurements were distorted to such an extent that the half-time reappearance could only be approximated.

Evaluation of the rate and effectiveness of erythroid marrow production was obtained from the plasma radioiron turnover (PIT) and marrow utilization of radioiron (4). Production rate was calculated by comparing the patient's PIT with the normal value of $0.65 \mathrm{mg}$ per $100 \mathrm{ml}$ of blood per day $(4,6)$. For example, a patient with a PIT of $0.91 \mathrm{mg}$ would have a production rate of $0.91 / 0.65$ $=1.4$ (times normal). Plasma iron concentration was determined by the method of Bothwell and Mallet (7), substituting the color reagent bathophenanthroline for dipyridyl and thioglycolic acid. For determining plasma unsaturated iron-binding capacity, the method of Ressler and Zak (8) was used. Hematocrits were measured either in Wintrobe tubes or with the microhematocrit centrifuge, and reticulocytes were quantitated from counts of 1,000 or more red cells on each of two paired coverslip smears. A Packard well-type gamma counter was used to measure $\mathrm{Fe}^{5 \theta}$ radioactivity, counting 10,000 or more counts above background. In vivo counting was performed with a movable, 2 -inch sodium iodide crystal probe, shielded, and collimated for iron with appropriate discriminator and scaler units $(4,9)$.

Phlebotomy procedure. Two adult males who had an overload of iron but no abnormalities in red cell production were subjected to repeated phlebotomy to stimulate erythropoiesis; patient L.T. was chosen for extensive study. For several months, he had a 500-ml phlebotomy each week. The amount was then increased to $1 \mathrm{~L}$ per week for 11 weeks, hypovolemia being avoided on each occasion by replacing $500 \mathrm{ml}$ or more of his own plasma. Then for 2 weeks, 400 to $500 \mathrm{ml}$ of blood was removed daily, with immediate replacement of an equal volume of plasma. Erythroid marrow production rates were calculated in two ways: 1) directly, by determining the "phlebotomy balance," i.e., the increment of marrow red cell output required to maintain the measured hematocrit after removal of a known amount of blood, and 2) indirectly, from the PIT, as described above.

Patients with hematological disorders. Patients were selected from certain categories of altered erythropoiesis in order to study the relationship between red cell $i$ activity and erythroid marrow function, as reflected by total red cell production and intramarrow maturation time. All patients tested are listed according to category in Table I, along with the hematocrit and reticulocyte percentages, corrected to a normal hematocrit of 42 . Those patients who were fully investigated (see Results) were kept on the Clinical Research ward of the University Hospital.

\section{Results}

Normal erythropoiesis stimulated by phlebotomy

Table II presents the hematocrit, reticulocyte count, marrow production rate, marrow maturation time, and titration scores of normal subject

TABLE I

Selected patients with hematological disorders

\begin{tabular}{lccc}
\hline \multicolumn{1}{c}{ Hematological class } & $\begin{array}{c}\text { Num- } \\
\text { ber }\end{array}$ & $\begin{array}{c}\text { Hema- } \\
\text { tocrit }\end{array}$ & $\begin{array}{c}\text { Corrected* } \\
\text { reticulo- } \\
\text { cyte \% }\end{array}$ \\
\hline Impaired marrow proliferation & & & \\
$\quad$ Idiopathic hypoplasia & 1 & 31 & 1.9 \\
Drug toxicity & 3 & $26-35$ & $0.8-1.7$ \\
Myelofibrosis & 1 & 30 & 2.0 \\
Acute leukemia & 2 & 23,26 & $0.5,0.8$ \\
Multiple myeloma & 2 & 18,25 & $0.4,0.8$ \\
Hemolytic disease & & & \\
PNH† & 2 & 19,27 & $4,7.5$ \\
Autoimmune hemolytic anemia & 3 & $20-32$ & $3-3.6$ \\
Idiopathic hemolytic anemia & 1 & 30 & 4.0 \\
Hereditary spherocytosis & 1 & 30 & 5.1 \\
Pyruvate kinase deficiency & 1 & 31 & 45 \\
G-6-PD deficiency & 1 & 42 & 17 \\
Sickle cell anemia & 1 & 26 & 9.8 \\
Ineffective erythropoiesis & & & \\
Defective hemoglobin synthesis & & & \\
$\quad$ Thalassemia & 18 & $10-30$ & $3-10$ \\
$\quad$ Di Guglielmo's anemia & 3 & $31-34$ & $1-1.5$ \\
Megaloblastic anemia & & & \\
$\quad$ Pernicious anemia & 4 & $17-35$ & $<0.5$ \\
$\quad$ Folic acid deficiency & 1 & 31 & 0.8 \\
\hline
\end{tabular}

* Corrected to a hematocrit of 42.

$+\mathrm{PNH}=$ paroxysmal nocturnal hemoglobinuria; G-6-PD = glucose 6-phosphate dehydrogenase. 
TABLE II

Changes in erythrokinetic measurements and titration scores associated with phlebotomy

\begin{tabular}{|c|c|c|c|c|c|c|c|c|}
\hline \multirow[b]{2}{*}{ Blood removed } & \multirow{2}{*}{$\underbrace{\text { Hema- }}_{\text {tocrit }}$} & \multirow{2}{*}{$\begin{array}{l}\text { Corrected } \\
\text { reticulo- } \\
\text { cyte \% }\end{array}$} & \multicolumn{2}{|c|}{$\begin{array}{c}\text { Marrow produc- } \\
\text { tion rate } \\
\text { (times normal) }\end{array}$} & \multirow{2}{*}{ 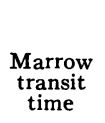 } & \multicolumn{3}{|c|}{ Titration scores } \\
\hline & & & $1 *$ & $2 \dagger$ & & $\mathrm{i}$ & $I$ & $\overline{\mathrm{H}}$ \\
\hline & & & & & days & & & \\
\hline None & 42 & 1.5 & 1 & 1.4 & 3.4 & 0 & 43 & 28 \\
\hline $500 \mathrm{ml}$ per week & 40 & 4.0 & 2.2 & & & $0-3$ & 43 & 26 \\
\hline $1,000 \mathrm{ml}$ per week & 37 & 8.2 & 3.5 & 3.6 & 2.8 & 10 & 47 & 28 \\
\hline $3,500 \mathrm{ml}$ per week & 24 & 15.3 & 5.2 & 4.9 & 1.6 & 23 & 44 & 25 \\
\hline
\end{tabular}

* Calculated from "phlebotomy balance" (see text).

$\dagger$ Calculated from plasma radioiron turnover (see text).

L.T. (blood group O) before phlebotomy and at three subsequent levels of marrow function. When $500 \mathrm{ml}$ of blood was removed per week, the marrow was able to keep up with the demand for red cells by producing them at a rate about 2.2 times normal. This was associated with very slight agglutinability of the cells by anti-i. When twice this amount of blood was removed weekly, red cell production lagged somewhat behind demand, the marrow maturation time decreased, and more $i$ activity was demonstrable on the red cells. Finally, when the blood removal reached $3,500 \mathrm{ml}$ per week, the patient became severely anemic with a hematocrit of 24 , despite a production rate over five times normal. At this time, there was further shortening of marrow maturation time to 1.6 days and an increase in i titration score to 23 . Phlebotomy was then discontinued. During the next 2 weeks, the hematocrit rose to 45 and the i titration score fell to 15 . Little observable change in $\mathrm{i}$ titration score occurred within the next 6-week period. Subsequently, small phlebotomies of less than $500 \mathrm{ml}$ per week were reinstituted, and several months later, no $i$ activity could be demonstrated.

The decrease in i titration score occurring during the recovery phase was interpreted as a dilution of the i-positive cell population by i-negative cells released into the circulation after cessation of continual marrow stress. The fact that i activity then stayed fairly constant for several weeks, at a time when most of the cells, being young, would be expected to remain viable, indicated persistence of the membrane phenomenon in the earlier released cells, possibly throughout their life-span.

As indicated in Table II, titration scores with anti- $\mathrm{I}$ and anti- $\mathrm{H}$ in this group $\mathrm{O}$ subject did not vary appreciably during the course of the investigation. Unlike the scores with anti-i, the minor variations observed with the other antibodies followed no consistent pattern. These and subsequent observations on other patients indicated that increased $\mathrm{i}$ activity was not simply a reflection of nonspecific agglutinability.

A second patient who had been subjected to less rigorous phlebotomy for several months produced red cells at a rate 2.4 times normal. His marrow transit time was 3.1 days, and his red cell i titration score, 0 before phlebotomy, was between 3 and 10 on several occasions. A third patient with prolonged gastrointestinal bleeding and a very active marrow had an i titration score of 10 . With successful treatment and correction of his severe anemia, the i activity gradually disappeared. Three other subjects whose red cells were tested within a few days of severe acute bleeding episodes had no demonstrable i activity

TABLE III

Marrow production rate and transit time compared with $i$ titration score in patients with hematological disorders

\begin{tabular}{|c|c|c|c|}
\hline Hematological class & $\begin{array}{c}\text { Produc- } \\
\text { tion rate } \\
\text { (times } \\
\text { normal) }\end{array}$ & $\underset{\text { time }}{\text { Transit }}$ & i score \\
\hline & & days & \\
\hline Impaired marrow proliferation & $.9-1.8$ & $1.8-2.7$ & $10-46$ \\
\hline \multicolumn{4}{|l|}{ Hemolytic disease } \\
\hline Decompensated & $2.7-6.0$ & $1.6-2.1$ & $10-37$ \\
\hline Compensated* & 5.1 & 3.0 & 0,5 \\
\hline \multicolumn{4}{|l|}{ Ineffective erythropoiesis } \\
\hline \multicolumn{4}{|l|}{ Defective hemoglobin } \\
\hline synthesis & $4.0-9.5$ & $1.5-3.0$ & $20-48$ \\
\hline Megaloblastic anemia & $1.4-3.5 \dagger$ & $3.3-5.5 \dagger$ & 0 \\
\hline
\end{tabular}

* Represents the one patient with glucose-6-phosphate dehydrogenase

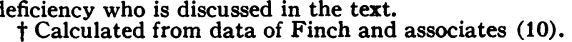


in spite of elevated reticulocyte counts and variable degrees of anemia. From this observation, it was inferred that a detectable change in this red cell membrane characteristic only occurs when the marrow has been under stress for a period of several days, or even weeks.

The results obtained from phlebotomized subjects showed that red cell agglutinability by anti-i could be induced by subjecting the marrow to a sustained demand. Studies of the patients with pre-existing hematological disorders were then undertaken; the results are summarized in Table III.

\section{Impaired proliferation of erythroid marrow}

These patients had anemia because their diseased marrow could not respond to either normal or increased demands for red cell production. As shown in Table I, the nine subjects studied represented several etiologies; their hematocrits varied from 18 to 35 and reticulocyte counts from 0.4 to $2.0 \%$. Both ferrokinetic studies and anti-i titrations were performed on three patients (idiopathic hypoplasia, myelofibrosis, and drug toxicity), and the other six were tested for red cell antigen activity only.

Marrow production rates of the three tested subjects varied from 0.95 to 1.8 , but the maturation time was shortened (1.8 to 2.7 days). All nine patients had some elevation in i titration score, ranging from 10 to 46 . One patient with multiple myeloma who had no red cell i activity before treatment with L-phenylalanine mustard became i-positive when anemia developed as the result of drug-induced marrow depression. Cessation of treatment was followed by return to a normal hematocrit and gradual disappearance of i activity.

\section{Hemolytic disease}

These ten patients had a chronic hemolytic process with increased, effective bone marrow production. The red cells of all of these patients were tested for $i$ activity. With the exception of the patient with sickle cell anemia and the three subjects with Coombs-positive anemia, all had ferrokinetic studies. Nine of the ten were anemic, indicating inability of the marrow to compensate for red cell destruction. These nine had moderate to marked elevation in i titration score (10 to 37), and in the five tested, the marrow maturation time was shortened (1.6 to 2.1 days). The only patient who was not anemic, a Caucasian male whose hemolytic disease was secondary to glucose-6phosphate dehydrogenase deficiency, remained well compensated (hematocrit 42) during several weeks of observation, and his red cells were not agglutinated by anti-i despite a marrow production rate five times normal. However, when he developed cholecystitis and mild anemia (hematocrit 35), his i titration score rose slightly to five. During this episode, the marrow maturation time, not previously determined, was 3.0 days.

\section{Ineffective erythropoiesis}

Patients in this general category are anemic because most of their marrow erythropoietic activity does not contribute to the circulating red cell mass, due to intramarrow destruction and rapid removal of newly released defective cells by the spleen or liver. For these studies such patients were subdivided into two broad classes:

1) Megaloblastic anemias. Four subjects with untreated pernicious anemia and one with folic acid deficiency were tested for red cell i activity, but none was found. Ferrokinetic studies could not be performed on these patients. However, appropriate calculations made from the data on six patients with this type of anemia previously studied by Finch and associates (10) indicated marrow production rates of 1.4 to 3.5 times normal, and normal to increased transit times of 3.5 to 5.5 days.

2) Defective hemoglobin synthesis. These 21 patients, 18 with a diagnosis of thalassemia major, had very active marrow proliferation. Five thalassemia patients and two with Di Guglielmo's anemia had ferrokinetic studies. These revealed the expected high production rates and a variable decrease in marrow maturation time (1.5 to 3.0 days). The $i$ titration score of this entire group of 21 patients was elevated (20 to 48 ).

\section{Tests with other antibodies}

Titrations with anti-I were performed on the red cells of 34 of the patients with elevated i scores. In addition, the $\mathrm{H}$ titration scores of 12 of the group $\mathrm{O}$ patients and $\mathrm{A}$ titration scores of 11 of the group $A_{1}$ patients were determined. These results, compared with the scores of normal con- 
TABLE IV

$I, H$, and A titration scores of patients and normal controls

\begin{tabular}{|c|c|c|c|c|c|c|c|}
\hline & \multirow[b]{2}{*}{ Antibody } & \multicolumn{3}{|c|}{ Patients } & \multicolumn{3}{|c|}{ Normal controls } \\
\hline & & $\begin{array}{c}\text { No. } \\
\text { tested }\end{array}$ & Range & Mean & $\begin{array}{c}\text { No. } \\
\text { tested }\end{array}$ & Range & Mean \\
\hline h & $\begin{array}{l}\text { Anti-I } \\
\text { Anti-H } \\
\text { Anti-A }\end{array}$ & $\begin{array}{l}34 \\
12 \\
11\end{array}$ & $\begin{array}{l}24-56 \\
25-33 \\
24-38\end{array}$ & $\begin{array}{l}42.1 \pm 7.2 \\
27.8 \pm 2.3 \\
32.5 \pm 4.2\end{array}$ & $\begin{array}{l}20 \\
16 \\
14\end{array}$ & $\begin{array}{l}29-55 \\
24-35 \\
25-40\end{array}$ & $\begin{array}{l}41.1 \pm 6.8 \\
29.7 \pm 3.1 \\
34.1 \pm 3.8\end{array}$ \\
\hline
\end{tabular}

trol subjects (blood bank donors), are indicated in Table IV. Although there was a wide range in antigen activity, there was no indication that the $i$ activity of the patients' red cells was associated with a general increase in susceptibility to agglutination by these other antibodies.

\section{Discussion}

In these studies, red cell agglutinability by anti-i could be demonstrated in normal subjects rendered anemic by bleeding as well as in most, but not all, anemic patients. In exploring the possible causes for this membrane phenomenon, we found that neither the severity of anemia nor the level of circulating reticulocytes could be directly correlated with i activity. Similarly, the rate of marrow proliferation was not a decisive factor. For example, in megaloblastic anemia and in compensated hemolytic disease, both associated with elevated marrow production rates, red cell i activity was not increased. Furthermore, although hypoplastic anemia was regularly accompanied by enhanced i scores, the same was true of thalassemia, characterized by a highly proliferative marrow.

On the other hand, all patients whose marrow maturation time was less than normal had some red cell i activity and, in general, the shorter the maturation time, the greater the $i$ activity. Additional evidence was obtained from the phlebotomy study, where the same inverse relationship was apparent. Difficulties in making a closer correlation include errors intrinsic in the methods as well as the probable existence of additional factors that modify cell membrane development. Furthermore, the studies on subject L.T. demonstrated persistence of $i$ reactivity, possibly throughout the lifespan of the red cell. The presence of i-positive cells in the peripheral blood at any given time cannot, therefore, be considered as an indicator of concomitant rapid marrow transit if marrow activity is not in a steady state.

As measured with $\mathrm{Fe}^{59}$, a shortening of the intramarrow maturation time merely indicates a decrease in the interval between $\mathrm{Fe}^{59}$ uptake by red cell precursors in the marrow and the appearance of their isotope-labeled progeny in the peripheral blood; it does not define the cytological mechanism. Some investigators have suggested (11, 12) that erythropoietin stimulates hemoglobin production in very young normoblasts so that rapid differentiation with "skipped mitosis" leads to early release of cells. However, effects on the later stages of erythroid maturation have also been observed $(13,14)$, an early release of reticulocytes and normoblasts from the marrow of rats occurring within hours after erythropoietin injection. This shift of reticulocytes from the marrow was also observed in response to rigorous phlebotomy of our experimental subject, L.T., as shown in Figure 2. With progressive shortening of the intramarrow maturation time, the number of circulating reticulocytes increased disproportionately to the marrow production rate, indicating that their early release from the marrow was associated wit? a prolongation of maturation in the peripheral blood. Thus, in this instance, the total maturation time (i.e., from normoblast to mature red cell) remained within the normal range.

Agglutinability by anti-i may be only one of several persistent abnormalities characteristic of cells prematurely released from the marrow. For example, such cells reportedly have a shortened life-span (15) and altered mean cell volume (16). This suggests that untimely departure from the marrow environment prevents continuation of the normal maturation process.

The chemical structure of the I and i red cell antigens has not been defined. Marcus, Kabat, and Rosenfield (17) showed that treatment of cells 


\begin{tabular}{|c|c|c|c|c|}
\hline \multirow[b]{2}{*}{$\begin{array}{c}\text { Blood } \\
\text { Removed } \\
\text { (ml per week) }\end{array}$} & \multirow[b]{2}{*}{$\begin{array}{c}\text { Morrow } \\
\text { Production } \\
\text { Rate }\end{array}$} & \multicolumn{2}{|c|}{ Maturation Time (Days) } & \multirow[b]{2}{*}{ Hemotocrit } \\
\hline & & $\begin{array}{c}\text { Marrow } \\
\text { Normoblossts ond } \\
\text { Reticulocytes }\end{array}$ & $\begin{array}{c}\text { Blood } \\
\text { Reticulocyles }\end{array}$ & \\
\hline 0 & 1 & 3.4 & $1: 5$ & 42 \\
\hline 1000 & 3.5 & 2.8 & 2.5 & 37 \\
\hline 3500 & 5.2 & 1.6 & 3.2 & 24 \\
\hline
\end{tabular}

Fig. 2. Shift of RED CELl PRECURSORS From MARrow TO PERIPHERAL BLOOD DURING REPEATED PHLEBOTOMY OF SUBJECr L.T. Maturation time in the marrow was determined from the radioiron reappearance curve (see Figure 1). Since the marrow production rate is an expression of total marrow activity and the corrected reticulocyte count represents a product of that activity, the greater the disproportion in the rise of reticulocytes over the rise in marrow production, the greater is the increase in reticulocyte maturation time in the peripheral blood. Therefore, the extramarrow maturation time was calculated by dividing the corrected reticulocyte percentage by the marrow production rate (obtained from Table II).

with $\beta$-galactosidase and $\beta$-glucosaminidase decreased their agglutinability by anti-I, particularly when the cells were group A. This finding, as well as the preferential agglutination by some samples of anti-I associated with ABO group (18), suggests that $\mathrm{I}$, and probably $\mathrm{i}$, antigenic determinants may contain sugar units resembling those of the ABO system. In addition, the recent studies of Schmidt, Barile, and McGinniss (19) indicate that red cell I activity, as measured by selected specimens of anti-I, may be greatly decreased in leukemia, a phenomenon that resembles the loss of $\mathrm{A}$ antigen in this disease. However, a similar loss of I or A activity or both was not observed in the patients with increased $\mathrm{i}$ activity described in this paper, a few of whom were tested with the anti-I used by Schmidt and his colleagues.

The reciprocal nature of $I$ and $i$ red cell antigens observed by Marsh (1) prompted him to consider the possibility that $\mathrm{i}$ represents the substrate from which I develops or that both $I$ and i develop on parallel pathways from a common substrate. The observations we have described offer no solution to this problem. However, it is tempting to speculate that in the normal adult, the early marrow normoblast might behave like its counterpart in fetal marrow in producing $\mathrm{i}$ substance. According to this hypothesis, the later normoblasts in adult marrow, unlike the fetal marrow cells, either utilize $\mathrm{i}$ for conversion to $\mathrm{I}$ or else shift from i to I production through a "switch" mechanism analogous to that postulated by Baglioni (20) for the change from $\gamma$ - to $\beta$-polypeptide chain production in the synthesis of hemoglobin. In either case, there is little residual $i$ on the cells entering the circulation. However, when excessive demand for red cells overtaxes the proliferative ability of the marrow, the compensatory response includes a shortening of intramarrow maturation time resulting in incomplete conversion of $i$ substrate to I or incomplete development of the switch mechanism. Once released from the marrow environment, the cells are unable to continue this conversion, and thus the membrane anomaly persists. However, in certain diseases such as vitamin $B_{12}$ deficiency, the nature of the defect results in normal or prolonged marrow maturation time regardless of the severe anemic stress, so that there is complete development of cytoplasmic and membrane components.

A very small number of hematologically normal subjects have hereditary inability to form I antigen, with the persistence of $i$ (1). With this unusual exception, there is no evidence that $i$ antigen is produced in appreciable amounts at any stage in the normally developing erythrocyte of adult marrow. In one nonanemic patient with pyruvatekinase deficiency whose peripheral cells were inegative, bone marrow collected and tested without attempt to separate its cellular elements reacted weakly with anti-i. However, no agglutination was observed when a single normal marrow specimen was similarly tested. Nevertheless, if i production was normally limited to the very earliest red cell precursors, reaction of such a small proportion of the total marrow population with a relatively weak antibody might easily escape detection.

One would expect that if $i$ is either the substrate for I or the product of a mechanism subsequently switched to I production, red cells with a marked increase of $i$ activity would have a corresponding decrease in I. Such an antithetical relationship, which is normally demonstrable during infancy (1), could not be shown in these patients nor in the progressively phlebotomized subject. However, titration with doubling dilutions of antibody is a very crude method of quan- 
titating antigen reactive sites. The use of $\mathrm{I}^{131}$ labeled antibodies might provide more accurate information if anti-i of sufficiently high titer becomes available. Evidence favoring a switch mechanism is also difficult to obtain. Since i reactivity is not invariably accompanied by a measurable increase in fetal hemoglobin (2), the two postulated changeovers (i.e., $\gamma$ - to $\beta$-globin polypeptide and $\mathrm{i}$ to $\mathrm{I}$ antigen synthesis) do not occur at the same stage of cellular development.

\section{Summary}

Agglutinability by the blood group antibody, anti-i, is a property normally confined to the red cells of infants, but it can be induced in normal adults by subjecting their marrow to the stress of repeated phlebotomy so that the intramarrow maturation time is progressively decreased. After bleeding is discontinued, newly developed cells are no longer i-positive, but the earlier released cells retain the membrane phenomenon.

Patients with anemia due to a variety of disorders also have acquired red cell $\mathrm{i}$ activity that can be correlated with rapid marrow transit but not with severity of anemia, marrow production rate, reticulocyte level, or fetal hemoglobin content. Furthermore, cells reacting with anti-i do not exhibit increased susceptibility to agglutination by other blood group antibodies such as anti-A, anti-H, and anti-I.

We suggest that the bone marrow environment may be a decisive factor in normal red cell maturation, and that the persistent $i$ activity of prematurely released cells may represent retention of a property that normally disappears at an early developmental stage within the marrow.

\section{Acknowledgments}

We are greatly indebted to Dr. C. A. Finch for his helpful advice and encouragement; we also wish to thank Miss Lucy Brooks for technical assistance.

\section{References}

1. Marsh, W. L. Anti-i : a cold antibody defining the Ii relationship in human red cells. Brit. J. Haemat. 1961, 7, 200.

2. Giblett, E. R., and M. C. Crookston. Agglutinability of red cells by anti-i in patients with thalassæmia major and other hæmatological disorders. Nature (Lond.) 1964, 201, 1138.

3. Race, R. R., and R. Sanger. Blood Groups in Man, 3rd ed. Oxford, Blackwell, 1958, p. 245.
4. Bothwell, T. H., and C. A. Finch. Iron Metabolism. Boston, Little, Brown, 1962, p. 8.

5. Finch, C. A., and D. H. Coleman. Erythropoiesis in man. Sang 1955, 26, 232.

6. Hillman, R. S., and E. R. Giblett. Unpublished observations.

7. Bothwell, T. H., and B. Mallett. The determination of iron in plasma or serum. Biochem. J. 1955, 59, 599.

8. Ressler, N., and B. Zak. Serum unsaturated ironbinding capacity. Amer. J. clin. Path. 1958, 30, 87.

9. Huff, R. L., P. J. Elminger, J. F. Garcia, J. M. Oda, M. C. Cockrell, and J. H. Lawrence. Ferrokinetics in normal persons and in patients having various erythropoietic disorders. J. clin. Invest. 1951, 30, 1512.

10. Finch, C. A., D. H. Coleman, A. G. Motulsky, D. M. Donohue, and R. H. Reiff. Erythrokinetics in pernicious anemia. Blood 1956, 11, 807.

11. Lajtha, L. G., and R. Oliver. Studies on the kinetics of erythropoiesis: a model of the erythron in Ciba Foundation Symposium on Haemopoiesis, G. E. Wolstenholme and M. J. O'Connor, Eds. London, Churchill, 1960, p. 289.

12. Stohlman, F., Jr., D. Howard, and A. Beland. Humoral regulation of erythropoiesis XII. Effect of erythropoietin and iron on cell size in iron deficiency anemia. Proc. Soc. exp. Biol. (N. Y.) 1963, 113, 986.

13. Gallagher, N. I., and R. D. Lange. Response to erythropoietin. Proc. Soc. exp. Biol. (N. Y.) 1962, $110,422$.

14. Gordon, A. S., J. LeBue, B. S. Dornfest, and G. W. Cooper. Reticulocyte and leukocyte release from isolated perfused rat legs and femurs in Erythropoiesis, L. O. Jacobsen and M. Doyle, Eds. New York, Grune \& Stratton, 1962, p. 321.

15. Stohlman, F., Jr. Humoral regulation of erythropoiesis VII. Shortened survival of erythrocytes produced by erythropoietine or severe anemia. Proc. Soc. exp. Biol. (N. Y.) 1961, 107, 884.

16. Stohlman, F., Jr., G. Lucarelli, D. Howard, B. Morse, and B. Leventhal. Regulation of erythropoiesis XVI. Cytokinetic patterns in disorders of erythropoiesis. Medicine (Baltimore) 1964, 43, 651.

17. Marcus, D. M., E. A. Kabat, and R. E. Rosenfield. The action of enzymes from Clostridium tertium on the I antigenic determinant of human erythrocytes. J. exp. Med. 1963, 118, 175.

18. Tippett, P., J. Noades, R. Sanger, R. R. Race, L. Sausais, C. A. Holman, and R. J. Buttimer. Further studies of the $\mathrm{I}$ antigen and antibody. Vox Sang (Basel) 1960, 5, 107.

19. Schmidt, P. J., M. F. Barile, and M. H. McGinniss. The I blood group, PPLO and leukemia (abstract). Blood 1964, 24, 834.

20. Baglioni, C. Correlation between genetics and chemistry of human hemoglobins in Molecular Genetics, J. H. Taylor, Ed. New York, Academic Press, 1963, p. 405. 